\title{
EFFECT OF ENDOSPERM AND SEED SIZE ON SOME YIELD AND QUALITY CHARACTERISTICS OF WHEAT (TRITICUM AESTIVUM L. EM THELL)
}

\author{
Hazim Serkan Tenikecier ${ }^{1 *}$, Temel Genctan ${ }^{1}$ \\ ${ }^{1}$ Tekirdag Namik Kemal University, Agriculture Faculty, Field Crops Department, 59030, Tekirdag, Turkey
}

Current Trends in

Natural Sciences

\begin{abstract}
The study was carried out with 3 bread wheat varieties (resistant KateA-1, sensitive Sultan 95, and middle resistant Golia) which are different response to drought. It was aimed to determine changes of some yield and quality characteristics in the wheat varieties with different seed size in the study. Artificial drought stress was created by chemical desiccant application (potassium chlorate with \%4) after 14 days to heading of varieties, and productions of undersized seeds were achieved in 2009-2010 growing season. Undersized seeds and normal seeds were sifted through sieves of different sizes, and different seed and endosperm sizes (control are over $2.5 \mathrm{~mm}, 2.0 \mathrm{~mm}$ and under $2.0 \mathrm{~m}$, desiccants are over $2.0 \mathrm{~m}$ and under $2.0 \mathrm{~m}$ ) were generated. Regarding of the results it was shown that variety KateA-1 that is resistant to drought gave better results than the others in different endosperm and seed sizes. To gather with decreases in seed size was shown reduces in characters such as grain yield, plant height, spike length, protein content, wet gluten content of the varieties. Gluten indexes values increased by decreases in grain size. No important statistical effects of seed size on number of spikelets per spike, number of grain per spike, grain weight per spike, number of tillers per plant, number of fertile tillers per plant, harvest index, spike index, thousand kernel weights and test weight were found. Among the desiccant treated seeds, the highest grain yield mean was obtained from seeds over $2.0 \mathrm{~mm}$ sieve of the varieties. In addition, it was shown that they gave results as well as control seeds over $2.5 \mathrm{~mm}$ and $2.0 \mathrm{~mm}$ sieve for the characters. According to results of the study, it is said that there is no inconvenient in the use as seed of grain over $2.0 \mathrm{~mm}$ sieve.
\end{abstract}

Keywords: bread wheat, drought, desiccant, quality, seed size, yield.

\section{INTRODUCTION}

Wheat, with 214 million hectares of cultivation and 735 million tons of production (Anonymous, 2020), is one of the most strategic products that provide nearly half of the protein needed by a $1 / 3$ of the world population and more than half of its daily calories, and has no alternative for humanity. Wheat, which has wide adaptability, can be grown in ecologies between latitudes $20-65^{\circ}$ north and $22-45^{\circ}$ south (Kün, 1996). Wheat is being harvested in the world at different times of the year. Heat stress affects the morphological traits in addition to physiological and biochemical responses within plant cell. The yield and quality of wheat are severely affected by heat stress in many countries (Kapadia et. al., 2017). In Turkey, wheat, with 7.28 million ha cultivation and production of 20 million tons, is the first place the product in terms of cultivation and production (Anonymous, 2020). It is the only non-alternative plant of Central Anatolia, Southeast Anatolia and Eastern Anatolia Regions. Although wheat is an indispensable product of arid and semi-arid regions, 
extremely hot and arid conditions lead to significant decreases in yield and quality (Balkan and Gençtan, 2013). In the developmental process of the wheat, it has been reported that the decrease in yield, which is caused by the high temperature stress, is related to the number of grain and grain weight per spike reduction (Tashiro and Wardlaw, 1990; Shpiler and Blum, 1991; Wardlaw and Wrigley, 1994; Plaut et. al., 2004; Hays et. al., 2007; Korkut et. al., 2017). Global warming, which we feel more and more of its negative effects especially in recent years, and drought arising from this, is one of the abiotic stress factors that threaten wheat production. As a result of excessive use of fossil fuels. In the atmosphere, the increase in the concentration of greenhouse gases such as carbon dioxide $\left(\mathrm{CO}_{2}\right)$, methane $\left(\mathrm{CH}_{4}\right)$, nitrooxide $\left(\mathrm{N}_{2} \mathrm{O}\right)$ and the return of the rays coming from the sun by reflecting it from the earth, and the rise of the temperature of our world are defined as "global warming" (Gençtan, 2012; Korkmaz, 2007; Kanber et al., 2010). In the present day, when the agricultural lands have reached their final limits, it is very important to pay attention to the development and cultivation techniques of the drought-resistant varieties in order to meet the wheat needed by the rapidly growing population and to reduce the product losses that will arise in the wheat in the coming years. Global warming and the resulting droughts have led to significant yield reductions in all agricultural products, in Turkey and all around the world. According to Turkey Statistical Institute (TUIK) 2007 data, the product losses incurred due to drought in the wheat was realized as $13.9 \%$. Product loss in wheat alone was about 2.5 million tones. Only loss was approximately 2.5 million tones in wheat. It is very important to pay attention to the development and cultivation techniques of wheat, which is needed by the rapidly growing population, to reduce the product losses that will arise due to global warming and drought. It is inevitable that the effects of global warming are clearly seen in wheat production, especially the seed production and seed quality will be adversely affected. The aim of this study to determine the ability of use the undersized grains as seeds for any drought stress as in the 2006-2007 growing period. For this purpose, it was aimed to determine the differences that may occur in the yield and quality elements of the undersized grains and different sizes obtained by creating artificial drought.

\section{MATERIALS AND METHODS}

In the research, the drought-resistant KateA1, medium-resistant Golia and drought-sensitive Sultan95 bread wheat varieties were used as materials. Varieties was sown in 2009-2010 growing season at Tekirdag Namik Kemal University, Faculty of Agriculture, Field Crops Department, Research and Experimental Area with plot seed drill at 500 plant $/ \mathrm{m}^{2}$ density, 6 rows of $5 \mathrm{~m}$ long and $17 \mathrm{~cm}$ row spacing. 14 days after the heading of varieties (Zadoks 69 periods) (Zadoks, et al., 1974) half of the plots sprayed with chemical desiccant (4\% $\mathrm{KClO}$-potassium chlorate) and artificial drought was created, plants are allowed to dry completely after 48 hours (Cseuz et al., 2002). Thus, it is ensured that grains with different size and endosperm content are formed. When the plants in the plots reached harvesting maturity, the chemical desiccant applied and not applied (control) parts were harvested separately. The grains obtained after harvest were passed through 2.5 and $2.0 \mathrm{~mm}$ sieves. One thousand weights of the grains obtained from plants applied and not applied desiccant (control) are given in Table 1. There were not obtained grains from top of $2.5 \mathrm{~mm}$ sieve (desiccant). It is noteworthy that, seeds with grain size above $2.0 \mathrm{~mm}$ sieve obtained from plants with desiccant applied in drought-resistant Kate A1 and moderately resistant Golia varieties have a thousand grain weight higher than seeds with grain size above $2.0 \mathrm{~mm}$ obtained from non-desiccated (control) plants. In drought-sensitive Sultan-95 variety seeds obtained from plants that did not applied desiccant (control) had a higher grain weight in all grain sizes than seeds obtained from plants that 


\section{Current Trends in Natural Sciences}

Vol. 9, Issue 17, pp. 132-141, 2020

https://doi.org/10.47068/ctns.2020.v9i17.015

Current Trends in Natural Sciences (on-line)

ISSN: 2284-953X

Current Trends in Natural Sciences (CD-Rom)

ISSN: 2284-9521

ISSN-L: 2284-9521

ISSN-L: 2284-9521

were treated with desiccant. This shows that under the artificial drought stress created by the application of chemical desiccant, the drought-resistant and moderately resistant varieties carry the reserve photosynthesis products stored in their organs such as stems and roots to a higher amount, so these varieties have higher translocation rates and amounts than the sensitive varieties. This is also an indication that grains of the same size have different endosperm contents.

Table 1. 1000 grain weight of varieties obtained from desiccant applied and not applied plants

\begin{tabular}{|c|c|c|}
\hline Varieties & Seed Sizes & 1000 grain weight $(\mathrm{g})$ \\
\hline \multirow{5}{*}{ KateA1 } & above $2.5 \mathrm{~mm}$ (control) & 26.9 \\
\hline & above $2.0 \mathrm{~mm}$ (control) & 25.1 \\
\hline & under $2.0 \mathrm{~mm}$ (control) & 16.7 \\
\hline & above $2.0 \mathrm{~mm}$ (desiccant) & 26.9 \\
\hline & under $2.0 \mathrm{~mm}$ (desiccant) & 14.2 \\
\hline \multirow{5}{*}{ Golia } & above $2.5 \mathrm{~mm}$ (control) & 32.7 \\
\hline & above $2.0 \mathrm{~mm}$ (control) & 20.3 \\
\hline & under $2.0 \mathrm{~mm}$ (control) & 12.1 \\
\hline & above $2.0 \mathrm{~mm}$ (desiccant) & 26.5 \\
\hline & under $2.0 \mathrm{~mm}$ (desiccant) & 11.7 \\
\hline \multirow{5}{*}{ Sultan-95 } & above $2.5 \mathrm{~mm}$ (control) & 30.0 \\
\hline & above $2.0 \mathrm{~mm}$ (control) & 22.1 \\
\hline & under $2.0 \mathrm{~mm}$ (control) & 13.3 \\
\hline & above $2.0 \mathrm{~mm}$ (desiccant) & 19.2 \\
\hline & under $2.0 \mathrm{~mm}$ (desiccant) & 12.3 \\
\hline
\end{tabular}

A field experiment was conducted during 2010-2011 wheat growing season (November-June) at Tekirdag Namik Kemal University, Faculty of Agriculture, Field Crops Department Research and Experimental Area. The experimental area was on loamy soil, (phosphorus content of $9.52 \mathrm{~kg} \mathrm{da}^{-1}$, potassium content of $137.7 \mathrm{~kg} \mathrm{da}^{-1}$, organic matter of $0.41 \%$ and $\mathrm{pH} 64$ ) with a total precipitation of $459.0 \mathrm{~mm}$, overall $78.0 \%$ relative humidity and an annual overall temperature of $11.4{ }^{\circ} \mathrm{C}$.

The experiment was conducted on Randomized Block Split Plot Design with three replications, cultivars were main plots and 5 different seed fractions were form sub plots. The experiment was hand sown on 08.10 .2010 in parcels of 5 meters long, $20 \mathrm{~cm}$ row spacing with 6 rows, with a planting frequency of 500 plants $/ \mathrm{m}^{2}$. Fertilization was performed with $4 \mathrm{~kg} \mathrm{da}^{-1}$ nitrogen and phosphorus during planting, $7.5 \mathrm{~kg} \mathrm{da}^{-1}$ nitrogen in the tillering period and $4 \mathrm{~kg} \mathrm{da}^{-1}$ nitrogen in the stem elongation period. The active ingredient after planting against weeds - Glean $75 \mathrm{DF}$, which is $75 \%$ Chlorsulfuron; In the spring, the Mustang, whose active ingredient is 2,4 D Acetate + Florasulam, and Puma Super, the active ingredient against wild oats Fenxoaprop-P-Ethyll was applied. When the plants in the plots reached full ripening (July 07, 2011), harvested with HEGE 160 combine harvester. In the research, the effects on different endosperm and grain size plant height, spike length, number of spikelets per spike, number of grain per spike, grain weight per spike, number of tillers per plant, number of fertile tillers per plant, harvest index, spike index, 1000 grain weight, test weight, grain yield, protein content, wet gluten content and gluten index were investigated. Measurements of the examined properties were made in the maturation period (Zadoks 92th period) (Zadoks et al. 1974). Statistical significance of the differences between the average values of the properties examined in the research using MSTAT-C software. Means were compared using a least significant difference (LSD) test (Düzgüneş et. al., 1987). 


\section{RESULTS AND DISCUSSIONS}

The results for the different endosperm and seed sizes on some yield and quality characteristics are given in Tables 2 to 4 . Regarding of the results it was shown that variety KateA-1 that is resistant to drought gave better results than the others in different endosperm and seed sizes. To gather with decreases in seed size was shown reduces in characters such as grain yield, plant height, spike length, protein content, wet gluten content of the varieties. Gluten indexes values increased by decreases in grain size. No important statistical effects of seed size on number of spikelets per spike, number of grain per spike, grain weight per spike, number of tillers per plant, number of fertile tillers per plant, harvest index, spike index, thousand kernel weights and test weight were found. Among the desiccant treated seeds, the highest grain yield mean was obtained from seeds over $2.0 \mathrm{~mm}$ sieve of the varieties. In addition, it was shown that they gave results as well as control seeds over $2.5 \mathrm{~mm}$ and $2.0 \mathrm{~mm}$ sieve for the characters. According to results of the study, it is said that there is no inconvenient in the use as seed of grain over $2.0 \mathrm{~mm}$ sieve.

Plant heights of varieties ranged from 65.43 to $109.01 \mathrm{~cm}$ (Table 2). The highest plant height was measured in Kate A1 variety, followed by Sultan-95 variety with $94.65 \mathrm{~cm}$. The shortest plant height is determined in Golia variety. According to the results of the research, it is noteworthy that, although there is no statistically significant difference in grain size, the longest plant height is obtained in $2.0 \mathrm{~mm}$ sieve grains of desiccated plants. Spike lengths of cultivars varied between 7.57-10.62 cm (Table 2). The longest spike was determined in Kate A1 variety, followed by Sultan95 variety, which is in the same statistical group as $10.48 \mathrm{~cm}$. The Golia variety had the shortest spikes. According to the research results, grain sizes were found statistically insignificant in terms of spike lengths. The number of spikelet's per spike of varieties used in the study varied between 17.52-20.86 (Table 2). The highest number of spikelet's was determined in Sultan-95 variety, followed by Kate A1 variety, which is in the same statistical group as 20.33. The least number of spikelets was observed in Golia variety. When the research results are examined, although the grain size is insignificant in the number of spikelet's in the spike, the number of spikelets in the spike of the desiccant plants was found to be more than the $2.0 \mathrm{~mm}$ under the sieve and over the sieve of the control plants. The number of grain in the spike varied between 36.57-48.88 (Table 2). According to the results of the research, although the number of seeds per spike is statistically insignificant, the maximum number of seeds per spike is obtained from the under $2.0 \mathrm{~mm}$ sieve grains of desiccated plants. As seen in Table 2, grain weight per spike of the cultivars used in the research varied between 1.08-1.33 g. The highest grain weight per spike was determined in the Kate-A1 cultivar and lowest in the Golia cultivar. Grain weights per spike obtained from grain size varied between 0.97-1.36 g, the highest grain weight per spike was obtained from above $2.5 \mathrm{~mm}$ sieve grains of control plants, followed by above $2.0 \mathrm{~mm}$ sieve grains of control plants. The lowest grain weight was determined in under $2.0 \mathrm{~mm}$ sieve grains of plants with desiccant application. The number of tillers per plant of the varieties used in the study ranged between 5.08-5.35 (Table 3). The maximum number of tillers per plant was determined in Kate A1 variety, followed by Sultan-95 variety in the same statistic group as 5.32. The least number of number of tillers per plant is in Golia variety. According to the results of the research, the number of siblings in the plant size was found statistically insignificant. According to the results of the research, the number of fertile tillers per plant was found to be insignificant in terms of grain size (Table 3), as the grain size decreased the number of fertile tillers per plant increased. According to the results of the research, the harvest index was found to be statistically insignificant in the grain size (Table 3), as the grain size decreased, the harvest index also decreased. Spike index of varieties 


\section{Current Trends in Natural Sciences}

Vol. 9, Issue 17, pp. 132-141, 2020

https://doi.org/10.47068/ctns.2020.v9i17.015

Current Trends in Natural Sciences (on-line)

ISSN: 2284-953X

Current Trends in Natural Sciences (CD-Rom)

ISSN: 2284-9521

ISSN-L: 2284-9521

ISSN-L: 2284-9521

Table 2. The mean values and significance groups of plant height, spike length, number of spikelets per spike, number of grain per spike, grain weight per spike

Plant Height (cm)

\begin{tabular}{|c|c|c|c|c|c|c|}
\hline \multirow[b]{2}{*}{ Varieties } & \multicolumn{5}{|c|}{ Grain Size } & \multirow[b]{2}{*}{ Mean } \\
\hline & $\begin{array}{c}\text { above } \\
2.5 \mathrm{~mm} \text { sieve } \\
\text { (control) }\end{array}$ & $\begin{array}{c}\text { above } \\
2.0 \mathrm{~mm} \text { sieve } \\
\text { (control) }\end{array}$ & $\begin{array}{c}\text { under } \\
2.0 \mathrm{~mm} \text { sieve } \\
\text { (control) }\end{array}$ & $\begin{array}{c}\text { above } \\
2.0 \text { mm sieve } \\
\text { (desiccant) }\end{array}$ & $\begin{array}{c}\text { under } \\
2.0 \text { mm sieve } \\
\text { (desiccant) }\end{array}$ & \\
\hline Kate A1 & 109.46 & 112.26 & 107.28 & 111.14 & 105.36 & $109.01 \mathrm{a}$ \\
\hline Golia & 67.30 & 64.33 & 64.75 & 66.56 & 64.20 & $65.43 \mathrm{c}$ \\
\hline Sultan-95 & 93.97 & 96.13 & 94.41 & 98.83 & 89.93 & $94.65 \mathrm{~b}$ \\
\hline Mean & 90.24 & 90.91 & 88.81 & 92.17 & 86.50 & 89.70 \\
\hline $\mathbf{L S D}(\mathbf{P} \leq \mathbf{0 . 0 0 5})$ & & Variety $=6.5$ & 3 Grain Size= & Variety x Gra & Size = - & \\
\hline \multicolumn{7}{|c|}{ Spike Length $(\mathrm{cm})$} \\
\hline \multirow[b]{2}{*}{ Varieties } & & 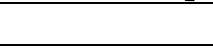 & Grain Size & & & \multirow[b]{2}{*}{ Mean } \\
\hline & $\begin{array}{c}\text { above } \\
2.5 \mathrm{~mm} \text { sieve } \\
\text { (control) }\end{array}$ & $\begin{array}{c}\text { above } \\
2.0 \mathrm{~mm} \text { sieve } \\
\text { (control) }\end{array}$ & $\begin{array}{c}\text { under } \\
2.0 \mathrm{~mm} \text { sieve } \\
\text { (control) }\end{array}$ & $\begin{array}{c}\text { above } \\
2.0 \mathrm{~mm} \text { sieve } \\
\text { (desiccant) }\end{array}$ & $\begin{array}{c}\text { under } \\
2.0 \text { mm sieve } \\
\text { (desiccant) }\end{array}$ & \\
\hline Kate A1 & 11.07 & 10.27 & 10.41 & 10.51 & 10.86 & $10.62 \mathrm{a}$ \\
\hline Golia & 7.68 & 7.66 & 7.60 & 7.36 & 7.54 & $7.57 \mathrm{~b}$ \\
\hline Sultan-95 & 10.71 & 10.37 & 10.21 & 10.65 & 10.48 & $10.48 \mathrm{a}$ \\
\hline Mean & 9.82 & 9.43 & 9.41 & 9.51 & 9.63 & 9.56 \\
\hline $\mathbf{L S D}(\mathbf{P} \leq \mathbf{0 . 0 0 5})$ & & Variety $=0.1$ & Grain Size= & Variety x Gra & S Size = - & \\
\hline \multicolumn{7}{|c|}{ Number of Spikelets per Spike (pcs) } \\
\hline \multirow[b]{2}{*}{ Varieties } & & & Grain Size & & & \multirow[b]{2}{*}{ Mean } \\
\hline & $\begin{array}{c}\text { above } \\
2.5 \mathrm{~mm} \text { sieve } \\
\text { (control) }\end{array}$ & $\begin{array}{c}\text { above } \\
2.0 \mathrm{~mm} \text { sieve } \\
\text { (control) }\end{array}$ & $\begin{array}{c}\text { under } \\
2.0 \mathrm{~mm} \text { sieve } \\
\text { (control) }\end{array}$ & $\begin{array}{c}\text { above } \\
2.0 \mathrm{~mm} \text { sieve } \\
\text { (desiccant) }\end{array}$ & $\begin{array}{c}\text { under } \\
2.0 \mathrm{~mm} \text { sieve } \\
\text { (desiccant) }\end{array}$ & \\
\hline Kate A1 & 21.20 & 19.33 & 20.08 & 20.42 & 20.61 & $20.33 \mathrm{a}$ \\
\hline Golia & 17.80 & 17.54 & 17.38 & 17.26 & 17.60 & $17.52 \mathrm{~b}$ \\
\hline Sultan-95 & 21.48 & 20.69 & 20.06 & 21.39 & 20.69 & $20.86 \mathrm{a}$ \\
\hline Mean & 20.16 & 19.19 & 19.17 & 19.69 & 19.63 & 19.57 \\
\hline $\mathbf{L S D}(\mathbf{P} \leq \mathbf{0 . 0 0 5})$ & & Variety $=1.8$ & Grain Size= & Variety x Gra & Size = - & \\
\hline \multicolumn{7}{|c|}{ Number of Grain per Spike (adet) } \\
\hline \multirow[b]{2}{*}{ Varieties } & & & Grain Size & & & \multirow[b]{2}{*}{ Mean } \\
\hline & $\begin{array}{c}\text { above } \\
2.5 \mathrm{~mm} \text { sieve } \\
\text { (control) }\end{array}$ & $\begin{array}{c}\text { above } \\
2.0 \mathrm{~mm} \text { sieve } \\
\text { (control) }\end{array}$ & $\begin{array}{c}\text { under } \\
2.0 \mathrm{~mm} \text { sieve } \\
\text { (control) }\end{array}$ & $\begin{array}{c}\text { above } \\
2.0 \mathrm{~mm} \text { sieve } \\
\text { (desiccant) }\end{array}$ & $\begin{array}{c}\text { under } \\
2.0 \mathrm{~mm} \text { sieve } \\
\text { (desiccant) }\end{array}$ & \\
\hline Kate A1 & 41.38 & 38.35 & 41.13 & 46.07 & 48.88 & 43.16 \\
\hline Golia & 40.44 & 37.77 & 36.57 & 38.22 & 41.41 & 38.88 \\
\hline Sultan-95 & 43.58 & 46.14 & 45.97 & 43.80 & 44.18 & 44.73 \\
\hline Mean & 41.80 & 40.75 & 41.22 & 42.69 & 44.82 & 42.26 \\
\hline $\mathbf{L S D}(\mathbf{P} \leq \mathbf{0 . 0 0 5})$ & & Variety $=1.8$ & Grain Size $=$ & Variety x Gra & $\mathrm{n}$ Size $=-$ & \\
\hline \multicolumn{7}{|c|}{ Grain Weight per Spike (g) } \\
\hline \multirow[b]{2}{*}{ Varieties } & & & Grain Size & & & \multirow[b]{2}{*}{ Mean } \\
\hline & $\begin{array}{c}\text { above } \\
2.5 \mathrm{~mm} \text { sieve } \\
\text { (control) }\end{array}$ & $\begin{array}{c}\text { above } \\
2.0 \mathrm{~mm} \text { sieve } \\
\text { (control) }\end{array}$ & $\begin{array}{c}\text { under } \\
2.0 \mathrm{~mm} \text { sieve } \\
\text { (control) }\end{array}$ & $\begin{array}{c}\text { above } \\
2.0 \text { mm sieve } \\
\text { (desiccant) }\end{array}$ & $\begin{array}{c}\text { under } \\
2.0 \mathrm{~mm} \text { sieve } \\
\text { (desiccant) }\end{array}$ & \\
\hline Kate A1 & 1.49 & 1.35 & 1.34 & 1.35 & 1.09 & $1.33 \mathrm{a}$ \\
\hline Golia & 1.26 & 1.12 & 1.02 & 1.04 & 096 & $1.08 \mathrm{~b}$ \\
\hline Sultan-95 & 1.31 & 1.16 & 1.04 & 1.08 & 0.85 & $1.09 \mathrm{~b}$ \\
\hline Mean & $1.36 \mathrm{a}$ & $1.21 \mathrm{~b}$ & $1.13 \mathrm{c}$ & $1.16 \mathrm{bc}$ & $0.97 \mathrm{~d}$ & 1.17 \\
\hline $\mathbf{L S D}(\mathbf{P} \leq \mathbf{0 . 0 0 5})$ & \multicolumn{6}{|c|}{ Variety $=0.100$} \\
\hline
\end{tabular}




\section{Current Trends in Natural Sciences}

Vol. 9, Issue 17, pp. 132-141, 2020

https://doi.org/10.47068/ctns.2020.v9i17.015

Current Trends in Natural Sciences (on-line)

ISSN: 2284-953X

Current Trends in Natural Sciences (CD-Rom)

ISSN: 2284-9521

ISSN-L: 2284-9521

ISSN-L: 2284-9521

Table 3. The mean values and significance groups of number of tillers per plant, number of fertile tillers per plant, harvest index, spike index, 1000 grain weights

Number of Tillers Per Plant (pcs)

\begin{tabular}{|c|c|c|c|c|c|c|}
\hline \multirow[b]{2}{*}{ Varieties } & \multicolumn{5}{|c|}{ Grain Size } & \multirow[b]{2}{*}{ Mean } \\
\hline & $\begin{array}{c}\text { above } \\
2.5 \mathrm{~mm} \text { sieve } \\
\text { (control) }\end{array}$ & $\begin{array}{c}\text { above } \\
2.0 \mathrm{~mm} \text { sieve } \\
\text { (control) }\end{array}$ & $\begin{array}{c}\text { under } \\
2.0 \mathrm{~mm} \text { sieve } \\
\text { (control) }\end{array}$ & $\begin{array}{c}\text { above } \\
2.0 \mathrm{~mm} \text { sieve } \\
\text { (desiccant) }\end{array}$ & $\begin{array}{c}\text { under } \\
2.0 \text { mm sieve } \\
\text { (desiccant) }\end{array}$ & \\
\hline Kate A1 & 5.54 & 5.24 & 5.43 & 5.17 & 5.37 & $5.35 \mathrm{a}$ \\
\hline Golia & 5.42 & 4.93 & 5.05 & 5.07 & 4.91 & $5.08 \mathrm{~b}$ \\
\hline Sultan-95 & 5.11 & 5.56 & 5.39 & 5.22 & 5.32 & $5.32 \mathrm{a}$ \\
\hline Mean & 5.36 & 5.24 & 5.29 & 5.15 & 5.20 & 5.25 \\
\hline $\mathbf{L S D}(P \leq 0.005)$ & \multicolumn{6}{|c|}{ Variety $=0.137$ Grain Size $=-\quad$ Variety $\times$ Grain Size $=-$} \\
\hline
\end{tabular}

\begin{tabular}{|c|c|c|c|c|c|c|}
\hline \multicolumn{7}{|c|}{ Number of Fertile Tillers Per Plant (pcs) } \\
\hline \multirow[b]{2}{*}{ Varieties } & \multicolumn{5}{|c|}{ Grain Size } & \multirow[b]{2}{*}{ Mean } \\
\hline & $\begin{array}{c}\text { above } \\
2.5 \mathrm{~mm} \text { sieve } \\
\text { (control) }\end{array}$ & $\begin{array}{c}\text { above } \\
2.0 \mathrm{~mm} \text { sieve } \\
\text { (control) }\end{array}$ & $\begin{array}{c}\text { under } \\
2.0 \mathrm{~mm} \text { sieve } \\
\text { (control) }\end{array}$ & $\begin{array}{c}\text { above } \\
2.0 \mathrm{~mm} \text { sieve } \\
\text { (desiccant) }\end{array}$ & $\begin{array}{c}\text { under } \\
2.0 \mathrm{~mm} \text { sieve } \\
\text { (desiccant) }\end{array}$ & \\
\hline Kate A1 & 3.44 & 3.37 & 3.21 & 3.15 & 3.16 & 3.26 \\
\hline Golia & 3.42 & 2.86 & 3.44 & 3.52 & 3.14 & 3.28 \\
\hline Sultan-95 & 2.60 & 3.28 & 3.26 & 3.01 & 3.14 & 3.06 \\
\hline Mean & 3.15 & 3.17 & 3.30 & 3.23 & 3.15 & 3.2 \\
\hline \multirow{2}{*}{\multicolumn{7}{|c|}{$\begin{array}{c}\text { Variety }=- \text { Grain Size }=-\quad \text { Variety x Grain Size }=- \\
\text { Harvest İndex }(\%)\end{array}$}} \\
\hline & & & & & & \\
\hline \multirow[b]{2}{*}{ Varieties } & & & Grain Size & & & \multirow[b]{2}{*}{ Mean } \\
\hline & $\begin{array}{c}\text { above } \\
2.5 \mathrm{~mm} \text { sieve } \\
\text { (control) }\end{array}$ & $\begin{array}{c}\text { above } \\
2.0 \mathrm{~mm} \text { sieve } \\
\text { (control) }\end{array}$ & $\begin{array}{c}\text { above } \\
2.0 \mathrm{~mm} \text { sieve } \\
\text { (control) }\end{array}$ & $\begin{array}{c}\text { above } \\
2.0 \mathrm{~mm} \text { sieve } \\
\text { (desiccant) }\end{array}$ & $\begin{array}{c}\text { under } \\
2.0 \mathrm{~mm} \text { sieve } \\
\text { (desiccant) }\end{array}$ & \\
\hline Kate A1 & 32.64 & 31.41 & 32.73 & 29.33 & 30.97 & 31.42 \\
\hline Golia & 39.51 & 38.23 & 38.12 & 36.89 & 39.95 & 38.54 \\
\hline Sultan-95 & 29.80 & 33.04 & 30.82 & 32.95 & 28.18 & 30.96 \\
\hline Mean & 33.98 & 34.23 & 33.89 & 33.06 & 33.03 & 33.64 \\
\hline $\mathbf{L S D}(\mathbf{P} \leq \mathbf{0 . 0 0 5})$ & \multicolumn{5}{|c|}{ Variety $=-\quad$ Grain Size $=-\quad$ Variety $\times$ Grain Size $=-$} & \\
\hline \multicolumn{7}{|c|}{ Spike İndeks (\%) } \\
\hline \multirow[b]{2}{*}{ Varieties } & \multicolumn{5}{|c|}{ Grain Size } & \multirow[b]{2}{*}{ Mean } \\
\hline & $\begin{array}{c}\text { above } \\
2.5 \mathrm{~mm} \text { sieve } \\
\text { (control) }\end{array}$ & $\begin{array}{c}\text { above } \\
2.0 \mathrm{~mm} \text { sieve } \\
\text { (control) }\end{array}$ & $\begin{array}{c}\text { under } \\
2.0 \mathrm{~mm} \text { sieve } \\
\text { (control) }\end{array}$ & $\begin{array}{c}\text { above } \\
2.0 \mathrm{~mm} \text { sieve } \\
\text { (desiccant) }\end{array}$ & $\begin{array}{c}\text { under } \\
2.0 \mathrm{~mm} \text { sieve } \\
\text { (desiccant) }\end{array}$ & \\
\hline Kate A1 & 67.90 & 66.03 & 66.83 & 70.05 & 68.19 & $67.80 \mathrm{~b}$ \\
\hline Golia & 74.54 & 71.69 & 70.61 & 75.79 & 71.68 & $72.86 \mathrm{a}$ \\
\hline Sultan-95 & 67.26 & 67.43 & 63.43 & 65.49 & 58.67 & $64.46 \mathrm{~b}$ \\
\hline Mean & 69.90 & 68.38 & 66.96 & 70.44 & 66.18 & 68.37 \\
\hline $\mathrm{LSD}(\mathrm{P} \leq \mathbf{0 . 0 0 5})$ & \multicolumn{5}{|c|}{ Variety $=4.661 \quad$ Grain Size $=-\quad$ Variety $x$ Grain Size $=-$} & \\
\hline \multicolumn{7}{|c|}{1000 Grain Weight (g) } \\
\hline \multirow[b]{2}{*}{ Varieties } & \multicolumn{5}{|c|}{ Grain Size } & \multirow[b]{2}{*}{ Mean } \\
\hline & $\begin{array}{c}\text { above } \\
2.5 \mathrm{~mm} \text { sieve } \\
\text { (control) }\end{array}$ & $\begin{array}{c}\text { above } \\
2.0 \mathrm{~mm} \text { sieve } \\
\text { (control) }\end{array}$ & $\begin{array}{c}\text { under } \\
2.0 \mathrm{~mm} \text { sieve } \\
\text { (control) }\end{array}$ & $\begin{array}{c}\text { above } \\
2.0 \mathrm{~mm} \text { sieve } \\
\text { (desiccant) }\end{array}$ & $\begin{array}{c}\text { under } \\
2.0 \mathrm{~mm} \text { sieve } \\
\text { (desiccant) }\end{array}$ & \\
\hline Kate A1 & 29.05 & 29.38 & 30.42 & 30.52 & 29.37 & 29.75 \\
\hline Golia & 27.25 & 27.15 & 27.62 & 28.33 & 28.18 & 27.71 \\
\hline Sultan-95 & 25.67 & 25.90 & 26.17 & 26.55 & 26.15 & 26.09 \\
\hline Mean & 27.32 & 27.48 & 28.07 & 28.47 & 27.90 & 27.85 \\
\hline $\mathbf{L S D}(\mathbf{P} \leq \mathbf{0 . 0 0 5})$ & \multicolumn{6}{|c|}{ Variety $=-$} \\
\hline
\end{tabular}




\section{Current Trends in Natural Sciences}

Vol. 9, Issue 17, pp. 132-141, 2020

https://doi.org/10.47068/ctns.2020.v9i17.015

Current Trends in Natural Sciences (on-line)

ISSN: 2284-953X

Current Trends in Natural Sciences (CD-Rom)

ISSN: 2284-9521

ISSN-L: 2284-9521

ISSN-L: 2284-9521

Table 4. The mean values and significance groups of test weight, grain yield, protein content, wet gluten content, gluten index

Test Weight (kg)

\begin{tabular}{|c|c|c|c|c|c|c|}
\hline \multirow[b]{2}{*}{ Varieties } & \multicolumn{5}{|c|}{ Grain Size } & \multirow[b]{2}{*}{ Mean } \\
\hline & $\begin{array}{c}\text { above } \\
2.5 \mathrm{~mm} \text { sieve } \\
\text { (control) }\end{array}$ & $\begin{array}{c}\text { above } \\
2.0 \mathrm{~mm} \text { sieve } \\
\text { (control) }\end{array}$ & $\begin{array}{c}\text { under } \\
2.0 \mathrm{~mm} \text { sieve } \\
\text { (control) }\end{array}$ & $\begin{array}{c}\text { above } \\
2.0 \mathrm{~mm} \text { sieve } \\
\text { (desiccant) }\end{array}$ & $\begin{array}{c}\text { under } \\
2.0 \mathrm{~mm} \text { sieve } \\
\text { (desiccant) }\end{array}$ & \\
\hline Kate A1 & 73.39 & 74.55 & 74.89 & 74.11 & 74.32 & 74.25 \\
\hline Golia & 71.48 & 71.67 & 71.45 & 72.76 & 72.09 & 71.89 \\
\hline Sultan-95 & 70.47 & 70.41 & 71.27 & 70.51 & 73.87 & 71.30 \\
\hline Mean & 71.78 & 72.21 & 72.54 & 72.46 & 73.43 & 72.48 \\
\hline $\mathbf{L S D}(P \leq 0.005)$ & & Variety $=$ & Grain Size $=-$ & riety x Grail & $e=-$ & \\
\hline
\end{tabular}

\begin{tabular}{|c|c|c|c|c|c|c|}
\hline \multicolumn{7}{|c|}{ Grain Yield $\left(\mathrm{kg} \mathrm{da}^{-1}\right)$} \\
\hline \multirow[b]{2}{*}{ Varieties } & \multicolumn{5}{|c|}{ Grain Size } & \multirow[b]{2}{*}{ Mean } \\
\hline & $\begin{array}{c}\text { above } \\
2.5 \mathrm{~mm} \text { sieve } \\
\text { (control) }\end{array}$ & $\begin{array}{c}\text { above } \\
2.0 \mathrm{~mm} \text { sieve } \\
\text { (control) }\end{array}$ & $\begin{array}{c}\text { under } \\
2.0 \mathrm{~mm} \text { sieve } \\
\text { (control) }\end{array}$ & $\begin{array}{c}\text { above } \\
2.0 \mathrm{~mm} \text { sieve } \\
\text { (desiccant) }\end{array}$ & $\begin{array}{c}\text { under } \\
2.0 \mathrm{~mm} \text { sieve } \\
\text { (desiccant) }\end{array}$ & \\
\hline Kate A1 & 355.33 & 360.42 & 335.93 & 343.30 & 312.64 & $341.52 \mathrm{~b}$ \\
\hline Golia & 468.37 & 431.77 & 397.74 & 455.89 & 355.83 & $421.92 \mathrm{a}$ \\
\hline Sultan-95 & 332.21 & 323.25 & 299.82 & 308.18 & 283.50 & $309.39 \mathrm{~b}$ \\
\hline Mean & $385.30 \mathrm{a}$ & $371.81 \mathrm{a}$ & $344.50 \mathrm{~b}$ & $369.12 \mathrm{a}$ & $317.32 \mathrm{c}$ & 357.61 \\
\hline $\mathbf{L S D}(\mathbf{P} \leq 0.005)$ & \multicolumn{6}{|c|}{ Variety $=64.406$ Grain Size $=19.781$ Variety $x$ Grain Size $=-$} \\
\hline
\end{tabular}

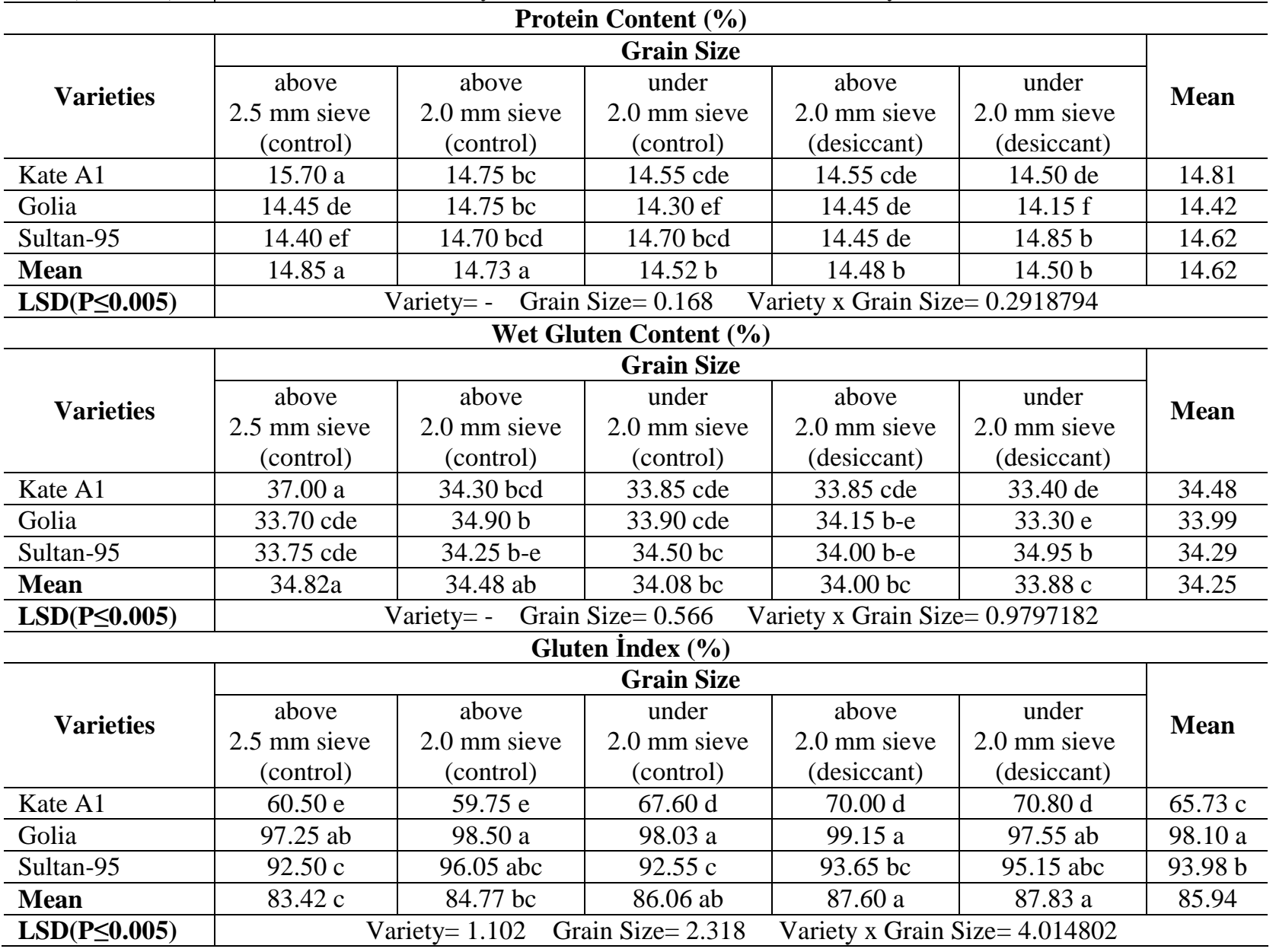


discussed in the study ranged from 64.46 to $72.86 \%$ (Table 3). The highest spike index was found in Golia variety, followed by Kate A1 variety with $67.80 \%$. The lowest spike index was found in Sultan-95 variety. According to the results of the research, the spike index was found to be statistically insignificant in grain size, generally the grain size decreased as the grain size decreased. However, the highest spike index was achieved in above $2.0 \mathrm{~mm}$ sieve grains of desiccated plants. According to the research results, thousand grain weights were found to be statistically insignificant in grain size and an increase was observed in the weight of a thousand as the grain size decreased (Table 3). According to the results of the research, the test weight was found to be statistically insignificant in grain size. As the grain size decreased, an increase in the test weight was observed (Table 4). The grain yields of the varieties ranged 283.50-448.37 kg da ${ }^{-1}$ (Table 4). The highest grain yield was obtained from Golia variety, followed by Kate A1 variety with $341.52 \mathrm{~kg} \mathrm{da}{ }^{-1}$. Sultan-95 variety had the lowest grain yield. Average grain yields obtained from grain sizes varied between $317.32-385.30 \mathrm{~kg} \mathrm{da}^{-1}$, the highest grain yield was obtained from above $2.5 \mathrm{~mm}$ sieve grains of control plants, and the lowest grain yield was obtained from under $2.0 \mathrm{~mm}$ sieve grains of desiccated plants (Table 4). It was understood that the grain yield decreases with the decrease in grain size. This decrease was greatest in under $2.0 \mathrm{~mm}$ sieve grains of desiccated plants. It is noteworthy that the yield obtained from above $2.0 \mathrm{~mm}$ sieve grains of desiccated plants is close to the yield obtained from above $2.0 \mathrm{~mm}$ sieve grains of control plants. This may be due to the high amount of nutrients (translocation amount) carried to the grains under stress conditions. The results is similar to Zareian et al. (2012), Todorović et al. (2011), Singh et al. (2010), Khan et al. (2000) whom indicated that with the decrease in grain size grain yield decreased. Mcdonald and Hussein (2017) reported that using large seed improved crop establishment and crop vigor but yield benefits of large seed were only achieved at higher yielding sites where the benefit was about $5 \%$, when grain yields were less that $2-2.5 \mathrm{tha}^{-1}$, there was no yield benefit from using large seed and in one instance, yields were reduced. In Table 4, it is seen that the protein content determined in grain sizes vary between $14.48-14.85 \%$. The highest protein content was found in the above $2.5 \mathrm{~mm}$ sieve grains of the control plants, followed by $14.73 \%$ above $2.0 \mathrm{~mm}$ sieve grains of the control plants. The lowest protein content was found in above $2.0 \mathrm{~mm}$ sieve grains of desiccated plants. The average protein content determined in the interaction of varietyxgrain size were seen to vary between 14.15-15.70\% (Table 4). The highest protein content was found in above $2.5 \mathrm{~mm}$ sieve grains of Kate A1 variety, followed by under $2.0 \mathrm{~mm}$ sieve grains of desiccant plants of Sultan-95 variety with $14.85 \%$. The lowest protein content was found in under $2.0 \mathrm{~mm}$ sieve grains of Golia variety of desiccated plants. According to the research results; it is seen that the protein content increases as the grain size decreases in the cultivated varieties. It is observed that the amount of wet gluten content determined in grain sizes varies between 33.88-34.82\%. The highest wet gluten content was found in above $2.5 \mathrm{~mm}$ sieve grains of control plants, followed by $34.48 \%$ of control plants above $2.0 \mathrm{~mm}$ sieve grains. The lowest wet gluten content was determined in under $2.0 \mathrm{~mm}$ sieve grains of desiccated plants. It is observed that the average wet gluten content determined in the interaction of variety $\mathrm{x}$ grain size varies between 33.30-37.00\% (Table 4). The highest wet gluten content was determined in above $2.5 \mathrm{~mm}$ sieve grains of Kate A1 variety. The lowest wet gluten content was determined in under $2.0 \mathrm{~mm}$ sieve grains of desiccated plants of Golia variety. When the research results are examined, it is noteworthy that as the grain size decreases, the amount of wet gluten decreases. Gluten index of varieties ranged between $65.75-98.10 \%$ (Table 4). The highest gluten index was obtained from Golia variety, followed by Sultan-95 variety with 93.98\%. Kate A1 variety had the lowest gluten index. As can be seen from Table 4, the gluten index of grain 
sizes varied between $83.42-87.83 \%$. The highest gluten index was found in under $2.0 \mathrm{~mm}$ sieve grains of desiccated plants, followed by above $2.0 \mathrm{~mm}$ sieve grains of desiccant plants in the same statistical group as $87.60 \%$. The lowest gluten index was obtained from above $2.5 \mathrm{~mm}$ sieve grains of control plants. The gluten index obtained from the interaction of variety $\mathrm{x}$ grain size varied between 59.75-99.15\% (Table 4). The highest gluten index of Golia cultivar was determined in under $2.0 \mathrm{~mm}$ sieve grain size of desiccated plants. According to the research results, as the grain size decreases, an increase in gluten index is observed.

\section{CONCLUSIONS}

There was no statistically significant difference between the varieties in terms of number of grains per spike, grain weight per spike, number of fertile tillers per plant, harvest index, test weight, 1000-grain weight, protein content and wet gluten content. It is observed that drought-moderate variety gave better results on gluten index while drought-sensitive variety gave better results on plant height, spike length, number of tillers per plant. When the varieties are examined in terms of some yield and quality characters in different grain sizes; as grain size decreases, grain yield, grain weight per spike, protein content, wet gluten content decreases, gluten index increases, plant height, spike length, number of spikelet per spike, number of grain per spike, number of tillers per plant, number of fertile tillers per plant, harvest index, spike index, 1000 grain weight and test weight did not change statistically. Results are supportive with Gadisa (2019) that whom reported larger seeds of spring wheat produced higher yields than smaller seeds under late-sown conditions but not under optimum management conditions and seed size not only influence emergence and establishment but also affected yield components and ultimately grain yield. In the light of these results; in order to minimize the pressure of global warming on wheat production, which we feel increasingly negative in recent years, it is seen that importance should be given to breeding and production of droughtresistant varieties. In the dry years such as the 2006-2007 production period, the production of qualified wheat seed is a big problem. In this experiment, it is aimed to answer the questions in mind about whether the use of undersized wheat grains as seeds due to drought will be correct. As a result, it can be said that if the above $2.0 \mathrm{~mm}$ sieve grains of the plants exposed to drought stress are used as seeds, the control plants can yield as good as the 2.0 and $2.5 \mathrm{~mm}$ grains.

\section{ACKNOWLEDGEMENTS}

This study was part of the Msc Thesis of Hazim Serkan TENIKECIER.

\section{REFERENCES}

Anonymus (2020). www.fao.org (29.02.2020)

Balkan, A., Gençtan, T. (2013). Effect of osmotic stress on germination and early seedling growth in bread wheat (Triticum aestivum L.). Journal of Tekirdag Agricultural Faculty (Jotaf) 10(2), 44-52

Cseuz, L., Pauk, J., Kertesz, Z., Matus, J., Fonad, P., Tari, I., Erdei, L. (2002). Wheat breeding for tolerance to drought stress at the cereals research non-profit company. Acta Biol. Szeged, 46(3-4), 25-26.

Düzgüneş, O., Kesici, T., Kavuncu, O., Gürbüz, F. (1987). Araştırma ve Deneme Metotları (İstatistik Metodları II). [Research and Trial Methods (Statistical Methods II)]. Ankara University, Agricultural Faculty Publications No.1021, 295 p. Ankara.

Gadisa, A. (2019). Review on the effect of seed source and size on grain yield of bread wheat (Tritium aestivum L.). $J$ Ecol \& Nat Resour, 3(1), 000155.

Gençtan, T. (2012). Agricultural Ecology. Namik Kemal University, Agricultural Faculty, General Publication No: 6, Textbook No:3, $354 \mathrm{~s}$, Tekirdağ

Hays, K., Maynard, I., Thomas, O., Bawden, M. (2007). Sources and types of confidence identified by world class sport performers. J. of Applied Sport Psychology 19, 434-56 


\section{Current Trends in Natural Sciences}

Vol. 9, Issue 17, pp. 132-141, 2020

https://doi.org/10.47068/ctns.2020.v9i17.015

Current Trends in Natural Sciences (on-line)

ISSN: 2284-953X

Current Trends in Natural Sciences (CD-Rom)

ISSN: 2284-9521

ISSN-L: 2284-9521

ISSN-L: 2284-9521

Korkmaz, K. (2007). Global Warming and Effect on Agricultural Applications. Alara Tarım, 6 (2), 43-49.

Kanber, R., Baştuğ, R., Büyüktaş, D., Ünlü, M., Kapur, B. (2010). Küresel iklim değişikliğinin su kaynakları ve tarımsal sulamaya etkileri [Effects of global climate change on water resources and agricultural irrigation]. Turkish Agricultural Engineering VII. Technical Congress, 1, 83-118, Ankara.

Kapadiya, K.B., Singh, C., Bhalara, R.L., Kandoliya, U.K., Dabhi K.H. (2017). Effect of higher temperature on leaf anatomy of heat tolerance and heat susceptible wheat genotypes (Triticum aestivum L.) by scanning electron microscopy. Journal of Pharmacognosy and Phytochemistry; 6(5), 2270-2277

Khan, R.U., Rashid, A., Khan, A., Khan, N.A. (2000). Yield component an seed yield of wheat as affected by seed size under the rain-fed conditions of dera Ismail Khan. Pakistan Journal of Biological Sciences 3(12), 1996-1997

Korkut Z.K., Balkan, A., Başer, İ., Bilgin, O. (2017). Determination of the high temperature stress tolerances of bread wheat genotypes. Journal of Life Sciences 11, 346-354

Kün, E. (1996). Tahıllar-I (Serin İklim Tahılları) [Cereals-I]. Ankara University, Agricultural Faculty Publications No. 1451, Textbook No. 431, 322s Ankara

Mcdonald, G.K., Hussein, S. (2017). The effects of wheat seed quality are greatest in high yielding environments. Proceedings of the 18th Australian Society of Agronomy Conference, 24 - 28 September 2017, Ballarat, Australia

Plaut, Z., Butow, B.J., Blumenthal, C.S., Wrigley, C.W. (2004). Transport 1085 of dry matter into developing wheat kernels and its contribution to grain yield under post-anthesis water deficit and elevated temperature. Field Crops Res. 86, 185-98.

Shpiler, L., Blum, A. (1991). Heat tolerance for yield and its components in different wheat cultivars. Euphytica. 51, 257-63.

Singh, T., Sharma, R.K., Pathania, M. (2010). Effect of seed size on growth and yield traits in durum wheat (Triticum durum L.) Agric. Sci. Digest., 30 (4), 258 - 261

Tashiro, T., Wardlaw, I.F. (1990). The effect of high temperature at different stages of ripening on grain set, grain weight, and grain dimensions in the semi-dwarf wheat 'banks'. Ann. Bot. 65, 51-61.

Todorovic, G., Protic, R., Protic, N. (2011). Variation of wheat grain yield depending on variety and seed size. Romanian Agricultural Research, No. 28, 25-28

Wardlaw, I. F., Wrigley, C.W. (1994). Heat tolerance in temperature cereals an overview. Austr. J. Plant Physiol. 21, 695-703.

Zadoks, J.C., Chang, T.T., Konzak, C.F. (1974). A decimal code for growth stages of cereals. Weed Res. 14, $415-421$.

Zareian, A., Yari, L.,Hasani, F., Ranjbar, G.H. (2012).Field performance of three wheat (Triticum aestivum L.) cultivars in various seed sizes. World Applied Sciences Journal 16 (2), 202-206. 